\title{
Landslide Hazards in the Seattle, Washington, Area
}

$\mathbf{T}$ he Seattle, Washington, area is known for its livability and its magnificent natural setting. The city and nearby communities are surrounded by an abundance of rivers and lakes and by the bays of Puget Sound. Two majestic mountain ranges, the Olympics and the Cascades, rim the region. These dramatic natural features are products of dynamic forces-landslides, earthquakes, tsunamis, glaciers, volcanoes, and floods. The same processes that formed this beautiful landscape pose hazards to the ever-growing population of the region. Landslides long have been a major cause of damage and destruction to people and property in the Seattle area.

\section{Seattle's geology and climate contribute to landslides}

The Seattle area was glaciated during the last ice age. The arrangement of glacial deposits and other weak rocks, along with the effects of coastal erosion, define where most landslides occur. Seattle has warm dry summers and cool moist winters. Average annual rainfall is about 37 inches and most landslides occur during the rainy season, which begins approximately in October or November and lasts through the following April or May. In general, landslides are common on coastal bluffs and other steep slopes. Glacial deposits consisting of layered silt earth flows, (3) soil topples and associated soil and rock falls, and (4) large, translational and rotational earth slides that are several meters to tens of meters deep. Shallow, rapidly moving translational slides are the most common type. They usually occur in loose sandy deposits that mantle steep slopes and on the headscarps and toes of large, deep-seated landslides. Most debris and earth flows begin as shallow translational slides; once the slides start moving, they transform to flows if enough water is present. The rapid movement of shallow slides and flows imparts significant destructive power. Soil topples and rock or soil falls occur mainly from steep outcroppings of till or other glacial deposits. Soil blocks topple (forward rotation out of the slope, below the center of mass of the soil block) from bluffs after cracks open within a few meters of the face of the bluff. Locally, soil topples pose a serious hazard, but few have caused major damage. Large deep landslides occur mainly on bluffs that overlook Puget Sound or Lake Washington, and they have caused severe damage to homes and infrastructure. These slides commonly occur in thick deposits of glacial outwash sand and till or in deposits of previous landslides. Most move slowly for periods of weeks to years, but some can also move rapidly.

\section{USGS landslide hazard studies for the Seattle area}

Following major landslides in 1996 and 1997, Seattle and other Puget Sound area communities resolved to reduce future landslide losses. Seattle commissioned Shannon \& Wilson, Inc., to compile a database of historical landslides from information and clay, sand, or sand and gravel, as well as other weak rocks of similar composition, occur throughout the area and are prone to landslides. Ground water tends to accumulate in the sand layers and weaken them by elevating pore pressures, especially where thick sand deposits rest on low permeability silt beds. Thus, many historical landslides have occurred in the thick deposits of glacial outwash sand found throughout the area. Deposits from these landslides form a topographic bench on many bluffs. Many recent landslides have occurred in the deposits and headscarps of previous landslides. Wave action constantly wears away the base of bluffs, which helps to maintain their steepness and contributes to recurrent landslide movement on the bluffs. Most slides occur after heavy winter rainfall soaks the ground and further weakens the soil. Major earthquakes in 1949, 1965, and 2001 have also caused landslides.

Four main types of landslides are common in the Seattle area, including (1) shallow translational earth slides, (2) debris flows and rapid

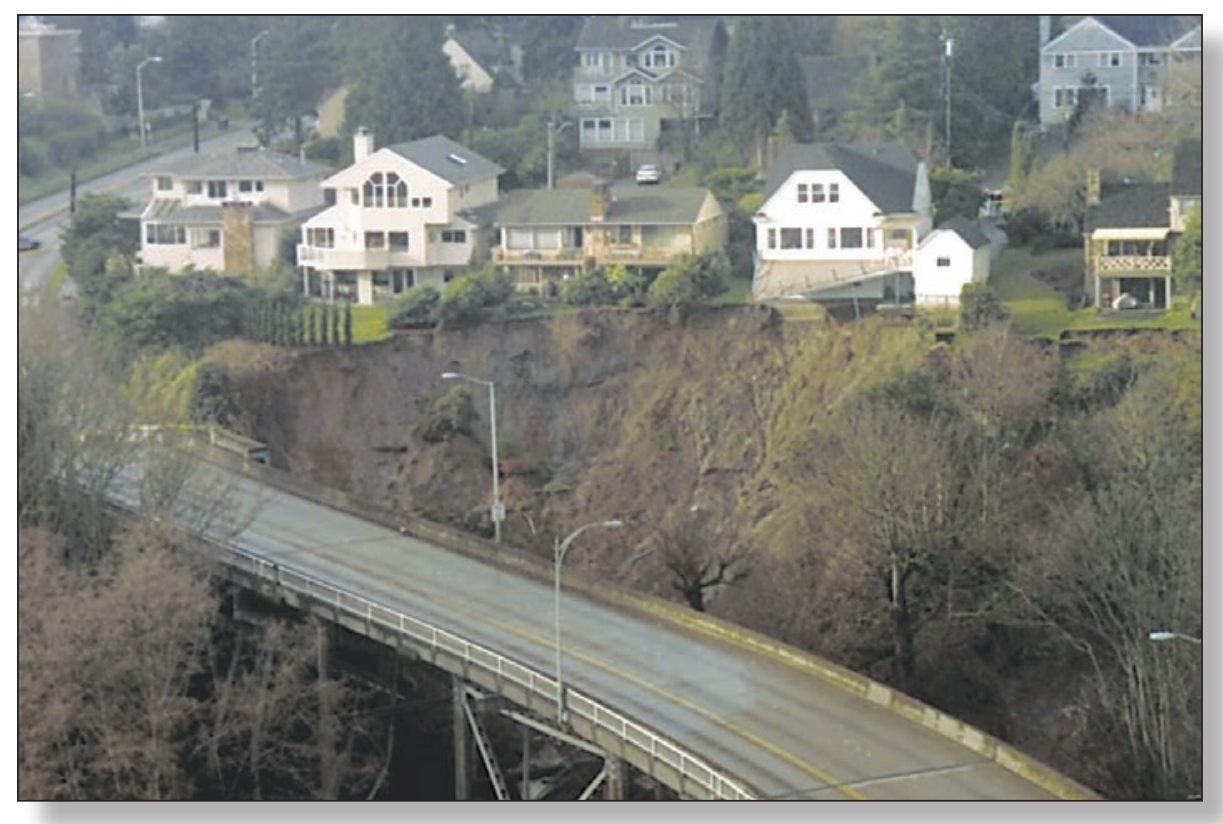

These houses overlook the Magnolia Bridge area of Seattle. The white house on the right side hangs precariously over the headscarp of a large landslide (photo by Hugh Shipman, Washington Department of Ecology). 
that the city and other groups had been collecting for about a century (see http://www.seattle.gov/DPD/Landslide/Study/default. asp). In 1998, the Federal Emergency Management Agency (FEMA) designated Seattle as a "Project Impact" city with the goal of encouraging the city to become more disaster-resistant to the effects of natural hazards. A major recommendation of the Project Impact council was that Seattle and the U.S. Geological Survey (USGS) collaborate to produce a landslide hazard map of the city. Related efforts to acquire high-resolution topographic data and to update geologic mapping of the city contributed greatly to development of the landslide maps. Cooperation of the city and the wealth of data that became available enabled the USGS to produce a suite of landslide maps and related products that include: (1) a shallow-landslide hazard map, (2) a landslideterrain map, (3) a landslide recurrence and probability map, (4) a hazard map for deep-seated landslides, (5) a landslide hazard map linked to rainfall intensity, and (6) rainfall thresholds for forecasting landslides. The Seattle landslide database allowed comparison of actual landslide locations and times with those predicted by modeling and analysis.

The following paragraphs briefly describe and illustrate some of the maps. Please see our website (http://landslides.usgs.gov) for the complete maps and for more detailed information.

\section{Shallow landslide hazard map}

The "Shallow Landslide Hazard map" (a portion shown in fig. 1) shows the susceptibility and relative hazard of Seattle slopes to shallow landslides, the most common type of rainfallinduced slope failure in Seattle. Shallow landslides are particularly hazardous to people and property because they often transform into debris flows, slurries of soil and rock that can travel rapidly (35-40 $\mathrm{mph}$ ) downslope. Recent geologic mapping, soil strength data, and high-resolution topographic data were used to evaluate the stability of each slope segment of the map. The stability was indexed and the results were compared with the landslide data set. The resulting map indicates categories of relative landslide hazard for the entire city of Seattle.

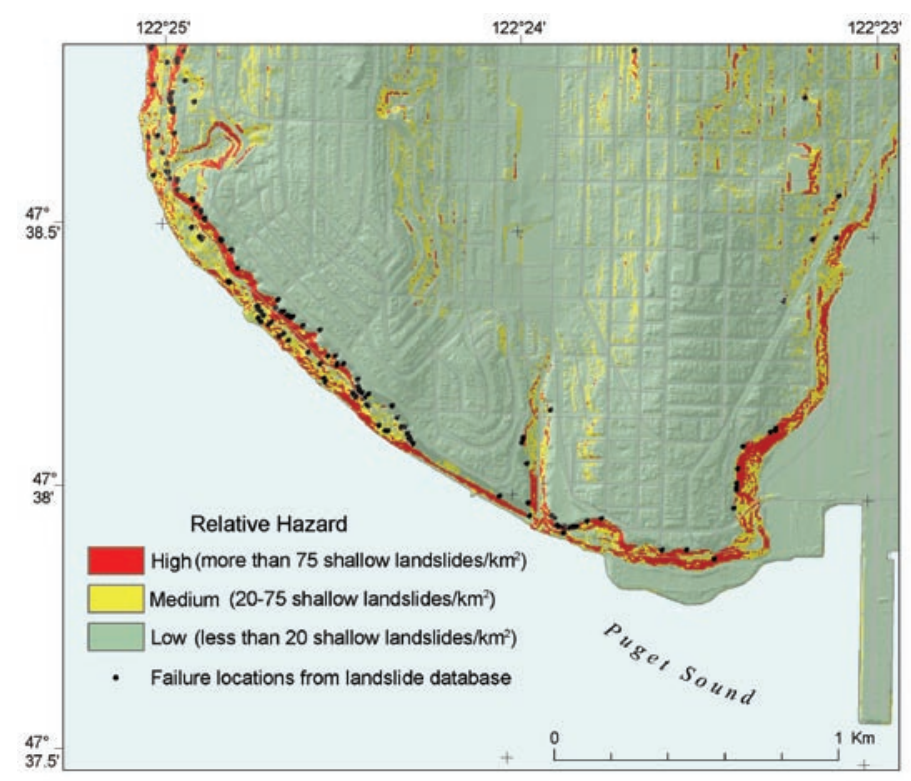

Figure 1. Portion of Shallow Landslide Hazard map showing part of the Magnolia area of Seattle.

\section{Landslide terrain map using LIDAR imagery}

The "Landslide Terrain map" (fig. 2) shows the geomorphology of the Seattle area for three kinds of landslide features-landslide headscarps, landslide deposits, and denuded slopes (slopes formed by mass wasting and erosion since retreat of glacial ice). This mapping effort involved the use of Light Distance and Ranging (LIDAR) data to expose landslide features in the many heavily vegetated areas in Seattle. Nearly all of the landslides mapped from this data are complexes consisting of numerous individual landslides. Mapped landslides, headscarps, and denuded slopes delineate areas of historical landslide activity more thoroughly than previous Seattle-wide landslide mapping efforts. More than $93 \%$ of about 1,300 reported historical landslides occurred within the boundaries of the LIDAR-mapped landforms. Virtually all (99.7\%) natural historical landslides occurred within these boundaries.

\section{Map of landslide probability and recurrence}

The "Landslide Probability and Recurrence map" (fig. 3) indicates annual probabilities for climatically induced landslides in Seattle. Seattle's historical landslide database was used to apply a time-dependent probabilistic approach to the evaluation of future landslides. Landslide probability values were established using the landslide database. Statistical analysis of the database showed that the annual probability of one or more landslides is $1 \%$ or greater for about $9 \%$ of the area of Seattle. Maximum annual probability of future individual landslides is $25 \%$ on a hillslope in west Seattle.

\section{Deep landslide hazards}

Deep landslides on the coastal bluffs of Puget Sound can cause extensive property damage. These slides typically are induced by ground-water conditions resulting from extended or successive wet winters rather than individual storms. Because they are large, their stability is controlled by three-dimensional

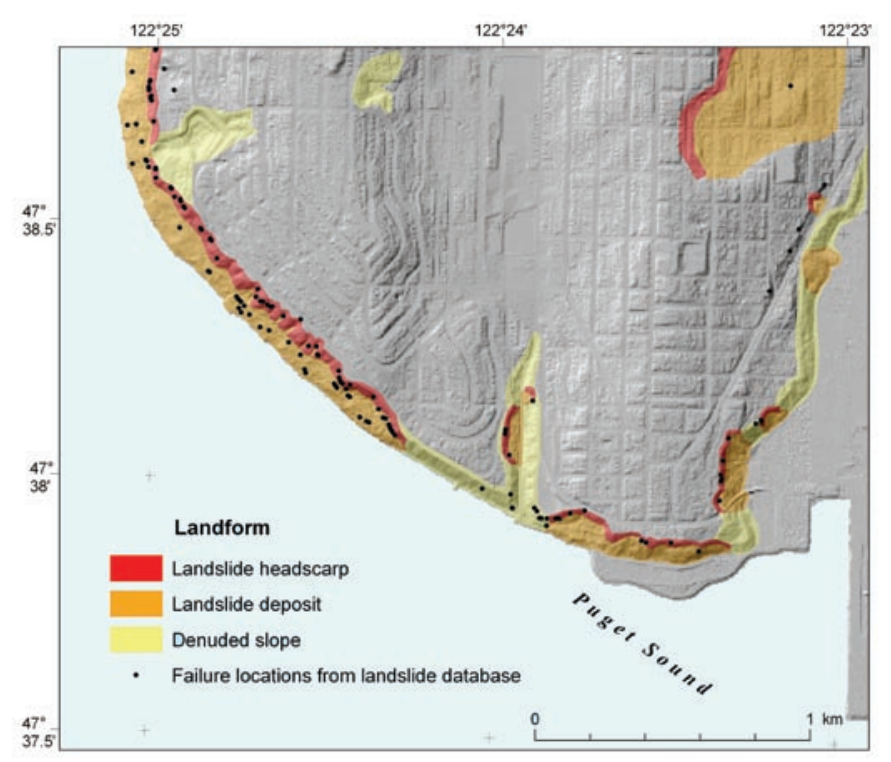

Figure 2. Portion of Landslide Terrain map showing part of the Magnolia area of Seattle. LIDAR imagery revealed landslide and erosion features in the yellow areas of the map and the features of large old landslides in the red and orange areas. Most historical landslides have also occurred in these areas. 
(3-D) effects, including complex 3-D ground-water flow as well as 3-D variations in strength and topography. A deep landslide hazard map (fig. 4) indicates the potential for these large landslides by showing the relative stability and instability of slopes on the bluffs of west Seattle.

The resulting map demonstrates that when slopes are dry, steepness and strength control potential instability. However, where ground water perches on lower permeability clay layers, extended wet winter conditions can increase the water table near the bluff face. Elevated ground-water pressures can lower slope stability. Given extended wet conditions, the 3-D analyses identify low stability areas in and adjacent to historically active deep-seated landslides.

\section{Forecasting landslides}

The exact time and location of landslides are very hard to predict even with sophisticated monitoring and models. Nevertheless, most landslides around Puget Sound occur during wet

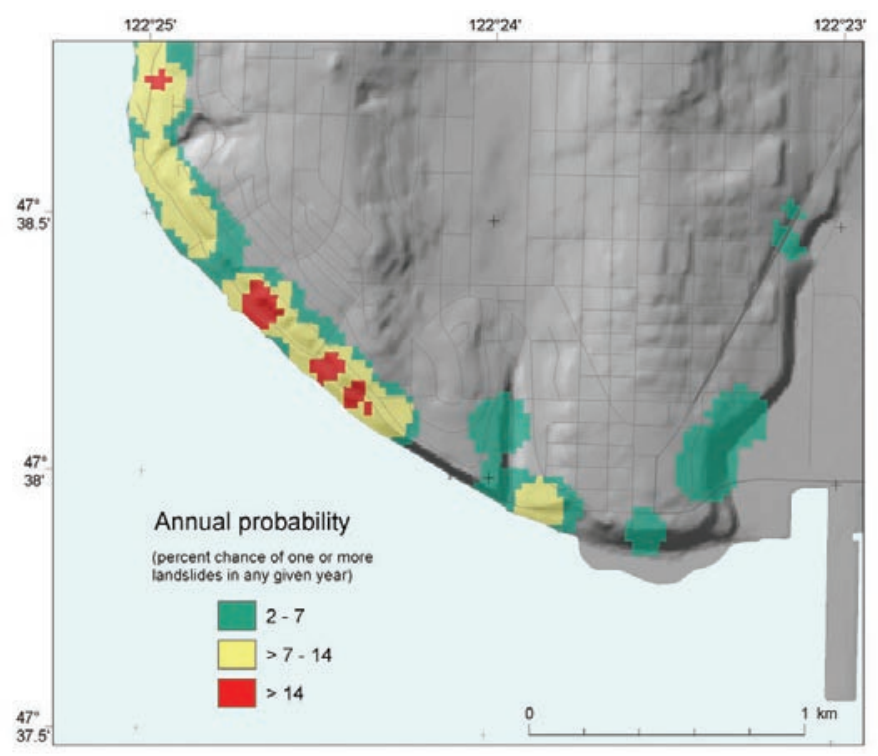

Figure 3. Portion of Landslide Probability and Recurrence map showing part of the Magnolia area of Seattle. Probabilities shown on this map were determined based on the frequency of historical landslides in each grid cell of the map.

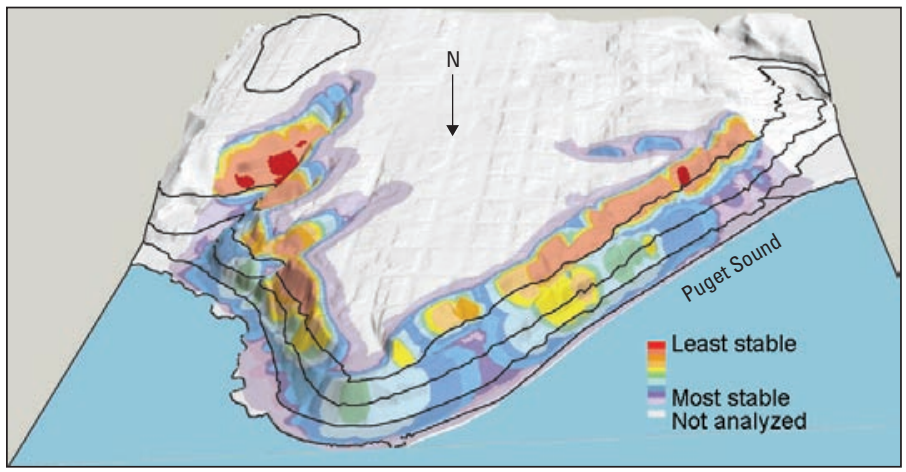

Figure 4. Potential for deep-seated landslides during wet winter conditions in the Duwamish Head area of Seattle (oblique aerial view toward south). Red and pink areas are considered most likely to produce large, deep-seated landslides. weather between October and April, so it is possible to know the general time when landslides are more likely to occur. Scientists at the USGS have developed methods and formulas based on past rainfall amounts to identify when landslides are likely. These formulas are called "precipitation thresholds." Two thresholds have been developed for the Seattle area. The first one, called the Cumulative Precipitation Threshold (fig. 5), tracks precipitation over the last 18 days and indicates when the ground is wet enough to be susceptible to landslides. Between 3.5 and 5.3 inches of rain are required to exceed this threshold, depending on how much rain has fallen in the last 3 days. The second, called the Intensity Duration Threshold (fig. 6), tracks rainfall during a storm and indicates when it is raining hard enough to cause multiple landslides if the ground is already wet.

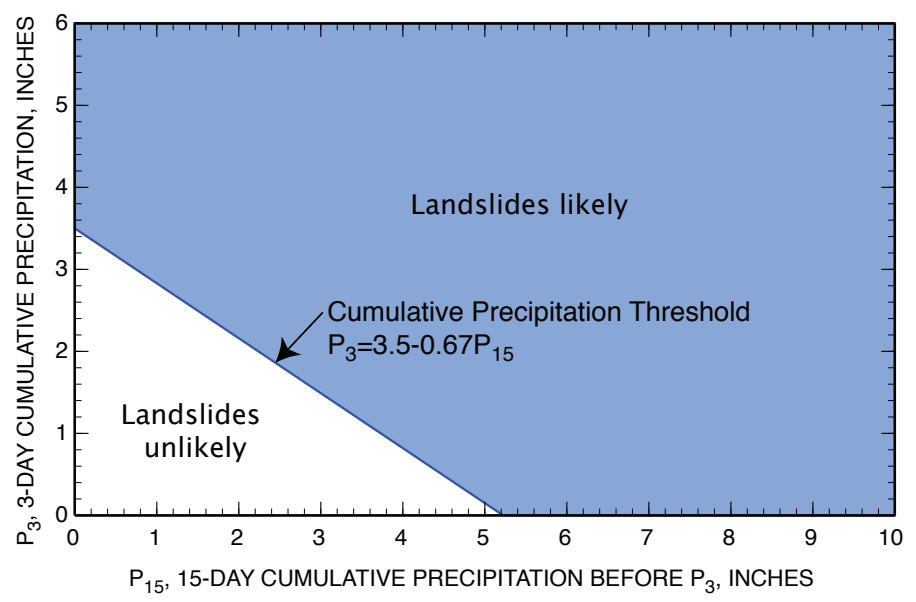

Figure 5. Cumulative Precipitation Threshold. When rainfall totals for the last 3 days (vertical axis) and the previous 15 days (horizontal axis) plot in the blue area of the graph (requires a combined total between 3.5 and 5.3 inches of rain over the 18-day period), the probability of landslides occurring is about $10 \%$.

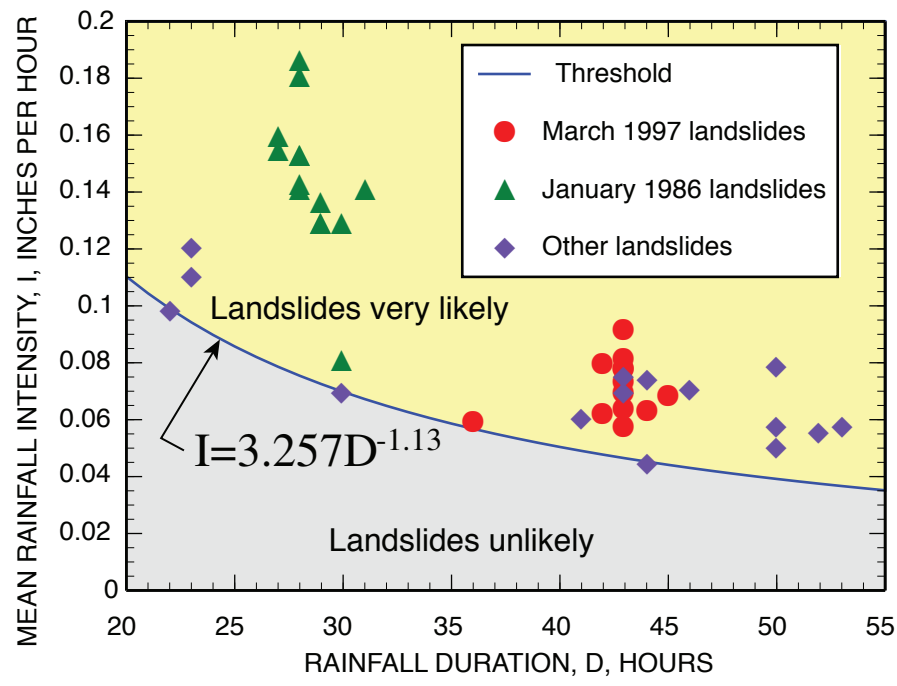

Figure 6. Intensity Duration Theshold. The graph, based on analysis of historical landslides, shows that a storm producing at least 2-3 inches of rain in 1-2 days is very likely to cause many landslides if the ground is already wet from recent rain. 
By comparing recent and forecast rainfall amounts to the thresholds, meteorologists, geologists, and city officials can help people know when to be prepared for landslides. The thresholds are accurate, but imperfect indicators of when landslides may occur. For example, statistical analysis of landslides that occurred between 1978 and 2003 showed that $85 \%$ of them occurred when the Cumulative Precipitation Threshold was exceeded. Also, the thresholds do not predict landslides caused by earthquakes or by construction. The thresholds work best in areas along the east side of Puget Sound, from Tacoma to Everett, but they can also give preliminary guidance in nearby areas, including Kitsap and Island Counties, the northern part of Thurston County, and the eastern part of Mason County. Additional data and analyses are needed to refine the thresholds for these areas and other parts of Washington State.

\section{How to access the maps and how to use them}

\section{Access}

Most of the landslide maps and information about the rainfall thresholds are available on-line. The Internet addresses of maps shown in figures 1, 2, and 3 and a report describing the rainfall thresholds (figs. 4 and 5) are listed below:

Chleborad, A.F., Baum, R.L., and Godt. J.W., 2006, Rainfall thresholds for forecastng landslides in the Seattle, Washington, area-Exceedance and probability: U.S. Geological Survey Open-File Report 2006-1064, accessed December 12, 2006, at URL http://pubs.usgs.gov/of/2006/1064/

Coe, J.A., Michael, J.A., Crovelli, R.A., and Savage, W.Z., 2000, Preliminary map showing landslide densities, mean recurrence intervals, and exceedance probabilities as determined from historic records, Seattle, Washington: U.S. Geological Survey Open-File Report 2000-303, accessed December 12, 2006, at URL http://pubs.usgs.gov/of/2000/ofr-00-0303/. Map available at http://pubs.usgs.gov/of/2000/ofr-00-0303/plate1.html

Harp, E.L., Michael, J.A., and Laprade, W.T., 2006, Shallowlandslide hazard map of Seattle, Washington: U.S. Geological Survey Open-File Report 2006-1139, accessed December 12, 2006, at URL http://pubs.usgs.gov/of/2006/1139/

Schulz, W.H., 2005, Landslide susceptibility estimated from mapping using light detection and ranging (LIDAR) imagery and historical landslide records, Seattle, Washington: U.S. Geological Survey Open-File Report 2005-1405, accessed December 12, 2006, at URL http://pubs.usgs.gov/of/2005/1405/

See http://landslides.usgs.gov/statelocalinfo/seattle/ for links to additional reports and information. A link to the deep landslide map will be added there once it is available.

\section{Use of the maps}

These USGS maps are intended as a general guide to landslide occurrence, not as a predictor of landslide hazard at specific sites in Seattle. These maps depict the potential for landslides from hillside source areas, but they do not depict landslide travel paths or areas of landslide deposition. The maps (figs. 1, 2, 3, and 4) do not take the place of an on-site survey or the professional judgment of a geologist or a geotechnical engineer. Appropriate uses of the maps include (1) storm preparedness planning for emergency access and response, (2) planning for development or redevelopment of hillside areas, and (3) municipal facility planning.

The maps shown in figures 1, 2, and 3 represent different but complementary ways of depicting potential landslide hazards in Seattle. Figure 1, based on simplified hydrologic and mechanical models of slope stability, depicts areas that are potentially unstable. Relative slope stability is classified on the basis of slope, a static surface water table, and average engineering properties of the geologic units, rather than historical landslide occurrence or landforms. This approach is somewhat less subjective than methods based on geomorphic interpretation and is not limited to areas of reported landslide occurrence. The geomorphic approach used to create the map shown in figure 2 depicts areas of past landslide occurrence over a longer time scale (since the last glacial retreat) than the historically based map in figure 3. Consequently, figure 2 gives a more complete picture than figure 3 of what areas have been affected by landslides and have potential for future landslides, provided that factors causing past slope instability continue to operate. The historically based probabilistic map shown in figure 3 is useful for identifying areas of frequent landslide damage so that city officials can set priorities in landslide mitigation efforts. However, historical landslides have been reported mainly in inhabited areas, and, thus, figure 3 gives little information on landslide occurrence or susceptibility of undeveloped hillsides.

\section{Where can I get more information?}

http://landslides.usgs.gov/ http://landslides.usgs.gov/statelocalinfo/seattle/

To see current Outlooks, http://landslides.usgs.gov/advisories/

Puget Sound area landslides and local weather, http://www.ecy.wa.gov/programs/sea/landslides/ http://www.wrh.noaa.gov/sew/

\section{How can I prepare for landslides?}

http://landslides.usgs.gov/statelocalinfo/seattle

\section{Also contact:}

Lynn Highland, U.S. Geological Survey Landslide Information Officer, phone: 1-800-654-4966, e-mail: highland@usgs.gov

Seattle Geology http://geology.wr.usgs.gov/wgmt/pacnw/pnwmap.html http://geomapnw.ess.washington.edu/index.php http://pubs.usgs.gov/of/2005/1252/ http://www.seattle.gov/projectimpact/pdfs/Sea_geo_map.pdf

Authors: Rex Baum, Ed Harp, and Lynn Highland Publication Layout: Margo Johnson, Denver Publishing Service Center 